\title{
Stress and Coping Mechanism among the Parents of Intellectual Disable Children
}

\author{
Bhawani Shahi Thakuri ${ }^{1}$ \\ ${ }^{1}$ Assistant Lecturer, College of Nursing \\ Nepalese Army Institute Health Sciences
}

\begin{abstract}
Background: High perceived stress levels and lack of effective coping skills could be a barrier to achieve the challenges of parenting process. Objectives: The study was conducted to find out the level of stress and coping strategies used by the parents of intellectual disable children. Methodology: A descriptive cross sectional quantitative research design was adopted among 100 respondents from three organizations. The study was conducted by using a Perceived Stress Index and Coping Inventory tools in Kathmandu valley. Result: It showed that three forth of parents had severe stress to clinical significant stress level during their parenting process. Parents were used to cope up stress by using various coping strategies like use of instrumental social support, positive reinterpretation and growth, planning, suppression of competing activities and use of emotional social support. Conclusion: Health educators should find out the most stressful areas and give a serious thought to encourage the use of healthy coping strategies to improve their parenting process.
\end{abstract}

KEYWORDS: Coping strategies, Intellectual Disable Children, Level of stress, Parent

\section{INTRODUCTION}

When parents learn that the child is having some form of disability, it causes enormous distress to them. They struggle to cope with the financial costs. Parents are also confronted with new and unexpected experiences. Parents with disabled child may have higher levels of stress and lower levels of well being than with normal children (Rangaswamy \& Bhavani, 2008).

The birth of a disabled child is an event that affects all the family members and both their internal and external relationships. The majority of families copes with the situation relatively well and is able to continue their life normally. However, coping with physically or intellectually disabled child is a highly individual process, and there is evidence to suggest that some families may never adjust fully to this event .To cope, the family uses its existing resources and strategies. Coping entail constantly changing cognitive and behavioral efforts to manage specific external and/or internal demands that are appraised as taxing the family's resources (Taanila, Syrjala, Kokkonen \& Jarvoelin,2001).

Very limited research has been done regarding assessing the stress level and coping strategies among parents of child with Intellectual disability in Nepal. Being a parent can be both rewarding and challenging even for parents of children without disabilities. The stress of having a child with intellectual disability causes impairment in fostering.The healthy coping mechanism plays the vital role for parenting process. It is important to find out the most stressful areas and gives a serious thought to encourage the use of healthy coping strategies to improve their parenting process. 


\section{METHODS}

Descriptive cross sectional quantitative design was used to assess the level of stress and coping strategies in this study. Study area was Patan Community Based Rehabilitation Organization, Nirmal Bal Vikas Kendra and Association for the Welfare of mentally Retarded. The eligible population for the study was all father or mother of children with intellectual disability and able to answer the questionnaire and their children had been admitted in the organization with diagnosed as intellectual disabilities.

Convenience sampling procedure was used to obtain the number of parents either father or mother of children with intellectual disability .The sample includes 40 from CBR, 30 from Nirmal Bal Vikas Kendra and 30 from AWMR. The total number of sample size was 100.

Respondents were interviewed with brief description of demographic information. Parenting Stress Index of Richard Abidin (1995) and coping inventory of Carver et al(1989) tools were asked. A low score to signify a low level of stress, and a high score to signify a high level of stress .Overall possible scores on the scale range from 36 - 160. The total coping inventory score was classified from less than 150 (not used coping strategies and more than 150(used coping strategies).

Collected datas were checked for its completeness and accuracy. All datas were rechecked after finishing the data collection program and kept in order for editing. The data has been analyzed by using different statistical techniques (mean, median, numbering, percentage, slandered deviation, and chi-square). Interpretation of the study has been done on the basis of analyzed data and objectives. Necessary findings have been made on the relevant tables. Data processing was done with the help of statistician.

\section{RESULTS}

Table 1. Demographic Information of Parents $(n=100)$

\begin{tabular}{|c|c|c|}
\hline Demographic Information & Categories & Percentage \\
\hline \multirow{4}{*}{ Age of the respondent } & $19-28$ & 24 \\
\hline & $29-38$ & 55 \\
\hline & $39-48$ & 20 \\
\hline & $49-58$ & 1 \\
\hline \multirow{2}{*}{ Sex of the respondent } & Male & 12 \\
\hline & Female & 88 \\
\hline \multirow{6}{*}{ Ethnicity of the respondent } & Janajati-advantages & 22 \\
\hline & Upper cast & 34 \\
\hline & Janajati-disadvantages & 34 \\
\hline & Muslim & 4 \\
\hline & Dalit & 4 \\
\hline & Madeshi-nondalit & 2 \\
\hline \multirow{4}{*}{ Religion of the respondent } & Hindu & 81 \\
\hline & Buddhist & 13 \\
\hline & Christian & 5 \\
\hline & Muslim & 1 \\
\hline \multirow{3}{*}{ Marital status of the respondent } & Married & 97 \\
\hline & Divorce & 1 \\
\hline & Widow & 2 \\
\hline Types of family & Joint & 61 \\
\hline
\end{tabular}




\begin{tabular}{|l|l|l|}
\hline \multirow{4}{*}{ Residence of the respondent } & Nuclear & 39 \\
\hline \multirow{5}{*}{ Education level of the respondent } & Local (within valley) & 53 \\
\cline { 2 - 3 } & Non-local (out of valley) & 47 \\
\hline & Illiterate & 20 \\
\cline { 2 - 3 } & Primary school & 16 \\
\cline { 2 - 3 } & Secondary school & 20 \\
\cline { 2 - 3 } & High school & 23 \\
\cline { 2 - 3 } & Pre-university & 12 \\
\cline { 2 - 3 } Occupation of Parents & Graduate & 9 \\
\hline \multirow{5}{*}{ Total family Income } & Home maker & 48 \\
\cline { 2 - 3 } & Business & 17 \\
\cline { 2 - 3 } & Service & 17 \\
\cline { 2 - 3 } & Agriculture & 11 \\
\cline { 2 - 3 } & Labour & 7 \\
\hline & $10,000-20,000$ & 49 \\
\cline { 2 - 3 } & $21,000-30,000$ & 8 \\
\cline { 2 - 3 } & $31,000-40,000$ & \\
\hline
\end{tabular}

The table 1 shows the demographic information of the parents with the child of Intellectual disability. Here the age group of the study population varied from 19 to 58 and almost half of the population that is $55 \%$ was from 29 to 38 years. Most of the respondents were female that is $88 \%$. Hinduism was the dominant of all other religion with $81 \%$. Almost $97 \%$ respondents were married. Most of the respondents $61 \%$ were from Joint family. More than half of the respondents were $61 \%$ as well $53 \%$ from joint family and within the valley respectively. Regarding their educational level, majority of the respondent $49 \%$ has completed high school. With respect to occupation most of them were involved in homemaker $48 \%$, and maximum respondent $49 \%$ had the total family income level was Rs 21,000 to 30,000 .

Table 2.Characteristics of children $(n=100)$

\begin{tabular}{|l|l|l|}
\hline \multirow{4}{*}{ Demography of the child } & Categories & \multicolumn{2}{|l|}{ Percentage } \\
\hline \multirow{3}{*}{ Sex of child } & $1-4$ years & 18 \\
\cline { 2 - 3 } & 5-8years & 33 \\
\cline { 2 - 3 } & $9-12$ years & 49 \\
\hline \multirow{2}{*}{ Place of delivery of child } & Male & 52 \\
\cline { 2 - 3 } & Female & 48 \\
\hline \multirow{3}{*}{ Types of delivery } & Home & 23 \\
\cline { 2 - 3 } & Hospital & 77 \\
\hline & Normal & 84 \\
\cline { 2 - 3 } & Operation & 14 \\
\cline { 2 - 3 } & Assisted (instrumental) delivery & 2 \\
\hline
\end{tabular}

The table 2 shows the demographic information of the children, here the age group of the study population varied from 1 to $12 \mathrm{yrs}$. Almost half of the respondents (49\%) were from age group 9 to 12 yrs and were (52\%) male. Three forth of the children (77\%) were hospital delivery and $84 \%$ were born by normal labour.

Table 3.Parental Stress Index

\begin{tabular}{|l|l|l|l|}
\hline Domains of stress & \multicolumn{1}{l}{ Statements } & Mean & \multicolumn{1}{l|}{ SD } \\
\hline Parental Distress & $1-12$ & 41.63 & 9.27 \\
\hline \hline
\end{tabular}

Vol. 1. No. II www.phdcentre.edu.np 
ISSN: 2362-1303 (Paper) | eISSN: 2362-1311(Online)

JOURNAL OF ADVANCED ACADEMIC RESEARCH (JAAR)

July 2014

\begin{tabular}{|l|l|l|l|}
\hline Parental child Interaction & $13-24$ & 41.65 & 8.50 \\
\hline Difficult child & $25-36$ & 39.74 & 8.1 \\
\hline
\end{tabular}

The table 3 represents the three domains of stress through the mean value and SD. In the statements, 1-12 represents parental distress, 13-24 represents parent-child difficult interaction and 25-36 represents difficult child. The least mean value (39.74) was found in difficult child. Table 4.Level of Stress $(n=100)$

\begin{tabular}{|l|l|}
\hline Parenting Stress Categories & Percentage \\
\hline Low Level of Stress & 0 \\
\hline Normal level of stress & 3 \\
\hline High level of stress & 21 \\
\hline Clinical significant & 76 \\
\hline
\end{tabular}

The table 4 shows the level of stress among the parents of children with intellectual disabled children. Three fourth (76\%) parents were in clinical significant stress and $21 \%$ parents were in high level of stress.

Table 5.Demographic Information and their stress level $(\mathrm{n}=100)$

\begin{tabular}{|c|c|c|c|c|}
\hline Demographic Information & Categories & $\begin{array}{l}\text { Normal level } \\
\text { of stress }\end{array}$ & $\begin{array}{l}\text { High level } \\
\text { of stress }\end{array}$ & $\begin{array}{l}\text { Clinical } \\
\text { significant }\end{array}$ \\
\hline \multirow[t]{2}{*}{ Sex of the respondent } & Male & 1 & 3 & 8 \\
\hline & Female & 2 & 18 & 68 \\
\hline \multirow{3}{*}{$\begin{array}{l}\text { Marital status of the } \\
\text { respondent }\end{array}$} & Married & 3 & 21 & 73 \\
\hline & Divorce & 0 & 0 & 1 \\
\hline & Widow & 0 & 0 & 2 \\
\hline \multirow[t]{5}{*}{ Occupation } & Homemaker & 3 & 10 & 35 \\
\hline & Business & 0 & 5 & 12 \\
\hline & service & 0 & 2 & 15 \\
\hline & agriculture & 0 & 4 & 7 \\
\hline & Labour & 0 & 0 & 7 \\
\hline \multirow[t]{2}{*}{ Education } & Up to High School & 2 & 1 & 53 \\
\hline & $\begin{array}{l}\text { Above High } \\
\text { School }\end{array}$ & 2 & 1 & 41 \\
\hline \multirow[t]{2}{*}{ Types of family } & Nuclear & 0 & 12 & 27 \\
\hline & Joint & 3 & 9 & 49 \\
\hline \multirow[t]{3}{*}{ Total Income of the family } & $10,000-20,000$ & 1 & 7 & 35 \\
\hline & $21,000-30,000$ & 1 & 13 & 35 \\
\hline & $31,000-40,000$ & 1 & 1 & 6 \\
\hline
\end{tabular}

The table 5 shows demographic information and the influence on stress level. In males, a stress level of only $8 \%$ was clinically significant while in females it was $68 \%$. The respondents showing High (21\%) as well as clinically significant (73\%) levels of stress were married .It can be seen that skilled workers and business occupants were found to have the low levels of stress, showing 35\% homemaker had clinically significant stress. Higher clinically significant stress level $(49 \%)$ was found in respondents living in joint families as compared to those living in nuclear families. The respondents who were educated up to high school were found to have the highest clinically significant stress levels (53\%). High clinically significant levels (35\%) were found in parents with incomes between Rs.11000 to Rs.20000and 21000-30000 simultaneously. 
JOURNAL OF ADVANCED ACADEMIC RESEARCH (JAAR)

July 2014

The data also indicates that as the income level of the parents increases the stress level tends to decrease.

Table 6 .Parenting Coping strategies $(n=100)$

\begin{tabular}{|l|l|l|} 
Coping Strategies & $\begin{array}{l}\text { Not used coping responses in } \\
\text { percentage }\end{array}$ & $\begin{array}{l}\text { Used coping responses in } \\
\text { percentage }\end{array}$ \\
\hline Positive reinterpretation and growth & 12 & 88 \\
\hline Mental disengagement & 30 & 70 \\
\hline Focus on and venting & 19 & 81 \\
\hline Use of instrumental social support & 8 & 92 \\
\hline Active coping & 17 & 83 \\
\hline Denial & 36 & 64 \\
\hline Religious coping & 20 & 80 \\
\hline Humor & 52 & 48 \\
\hline Behavioral disengagement & 34 & 66 \\
\hline Restraint & 25 & 75 \\
\hline Use of emotional social support & 14 & 86 \\
\hline Substance use & 71 & 29 \\
\hline Acceptance & 18 & 82 \\
\hline Suppression of competing activities & 14 & 86 \\
\hline Planning & 13 & 87 \\
\hline
\end{tabular}

The table 6 presents that $88 \%$ respondent were used of positive reinterpretation and growth coping strategies and mental disengagement coping strategies were used by $70 \%$. Rrespondents (81\%) were used of focus on and venting coping. Highest $92 \%$ respondent were used of use of instrumental social support coping. Rrespondents $83 \%$ were used active and $64 \%$ was used denial coping. Almost $80 \%$ respondent used religious coping .Least respondents 48 $\%$ were used humor and $66 \%$ respondent used behavioral disengagement .Three forth respondent $(75 \%)$ used restraint . Respondent $(86 \%)$ were used of emotional social support coping.

Here respondents $29 \%$ were used substance use coping and respondent $(82 \%)$ used acceptance, $86 \%$ respondent used of Suppression of competing activities and finally $87 \%$ respondent used planning coping.

Table 7. Parenting Coping Mean and SD

\begin{tabular}{|l|l|l|}
\hline Coping Strategies & Mean & SD \\
\hline Positive reinterpretation and growth & 1.88 & .32 \\
\hline Mental disengagement & 1.70 & .46 \\
\hline Focus on and venting & 1.81 & .39 \\
\hline Use of instrumental social support & 1.92 & .27 \\
\hline Active coping & 1.83 & .37 \\
\hline Denial & 1.64 & .48 \\
\hline Religious coping & 1.8 & .4 \\
\hline Humor & 1.48 & .5 \\
\hline Behavioral disengagement & 1.66 & .47 \\
\hline Restraint & 1.75 & .43 \\
\hline Use of emotional social support & 1.86 & .34 \\
\hline Substance use & 1.29 & .45 \\
\hline
\end{tabular}




\begin{tabular}{|l|l|l|}
\hline Acceptance & 1.82 & .38 \\
\hline Suppression of competing activities & 1.86 & .34 \\
\hline Planning & 1.87 & .33 \\
\hline
\end{tabular}

The table 7 shows the use of instrumental social support $(\mathrm{M}=1.92, \mathrm{SD}=0.27)$; positive reinterpretation and growth $(\mathrm{M}=1.88, \mathrm{SD}=0.32)$, planning $(\mathrm{M}=1.87, \mathrm{SD}=0.33)$. Here suppression of competing activities and use of emotional social support were the same value (M $=1.8, \mathrm{SD}=0.34)$. Least used two coping strategies included: Substance use $(\mathrm{M}=1.29, \mathrm{SD}=0.45)$ and humor $(\mathrm{M}=1.48, \mathrm{SD}=0.50)$

Table 8.Socio Demographic and Coping Strategies $(\mathrm{n}=100)$

\begin{tabular}{|c|c|c|c|}
\hline Demographic Information & Categories & $\begin{array}{l}\text { Not used coping } \\
\text { responses }\end{array}$ & $\begin{array}{l}\text { Used coping } \\
\text { responses }\end{array}$ \\
\hline \multirow{2}{*}{ Sex of the respondent } & Male & 2 & 10 \\
\hline & Female & 10 & 78 \\
\hline \multirow{2}{*}{ Education } & Up to high school & 8 & 48 \\
\hline & above high school & 4 & 40 \\
\hline \multirow{5}{*}{ Occupation } & Homemaker & 8 & 40 \\
\hline & Business & 0 & 17 \\
\hline & service & 1 & 16 \\
\hline & agriculture & 2 & 9 \\
\hline & Labour & 1 & 6 \\
\hline
\end{tabular}

The table 8 shows influence of demographic and coping strategies. Mothers (78\%) were more likely to use coping strategies than the father $(2 \%)$. In relation to the education , up to high school level respondent (48\%)and above high school (48\%) used coping strategies .Here the survey shows the influence of occupation on coping strategies that is : Home maker used coping responses was $40 \%$ and labour used coping strategies was only $6 \%$, that is lower than other occupation .

Table 12. Correlation between stress and coping

Correlation is significant at the 0.01 level.

\begin{tabular}{|l|l|l|}
\hline Variable & Coping & \multicolumn{2}{l|}{ Psychological stress } \\
\hline Psychological Stress & .532 & 1 \\
\hline Coping & 1 & .532 \\
\hline
\end{tabular}

Above table shows the correlation between cope and stress is 0.532 which is significantly correlation $(\mathrm{P}=0.01)$. As the stress score increases, coping also increases. In other word stress and coping were directly related.

\section{Discussion}

The findings of this study revealed that the parents of intellectual disable children experienced high stress $(21 \%)$ to clinically significant $(76 \%)$ stress which is similar to the findings of research done by Pakes, et.al. 2011. In Pakes research 26\% of the respondent reported high stress level and majority of the respondent were female (96\%) which was similar to the findings of this research was $(83 \%)$.

In this research income of the family has inverse relationship which is congruent to Ricketts and Anderson (2008) which was found that the parents of low level of income had more parental stress. Hindagmayam, (2010) also found a negative relationship between family income and parenting stress. This type of family was associated with parenting stress in which joint family had more parenting stress in comparison with nuclear family which was similar to the 
findings of Hindagmayam, (2010) which found that extended family had more parenting stress in comparison to nuclear family.

This study shows that the influence of parents' education and parenting stress with intellectual disabled children. The higher education group has less stress. The plausible reason might be as the parents are more educated, they are more aware of the needs and problems and are able to cope with the demands of the current situation. Higher education parents have less stress as they know how to manage the situation. This study is similar to Venkatesh Kumar (2008) in his study he found that educational level had significant influence on psychological stress where in higher the educational level lesser the stress. Similarly Vijesh and Sukumaran (2007) found non-significant differences in the educational level and stress experienced by mother of children with intellectual disability.

The five most frequently reported coping strategies included acceptance $(\mathrm{M}=12.97, \mathrm{SD}=$ 2.96), active Coping $(\mathrm{M}=12.85, \mathrm{SD}=2.81)$, positive reinterpretation and growth $(\mathrm{M}=12.48$, $\mathrm{SD}=2.51)$, suppression of competing activities $(\mathrm{M}=12.16, \mathrm{SD}=2.90)$ and planning $(\mathrm{M}=$ 12.11, SD = 2.84). (Peshi wang 2010) but in this research shows that the use of instrumental social support $(\mathrm{M}=1.92, \mathrm{SD}=0.2$, positive reinterpretation and growth $(\mathrm{M}=1.88, \mathrm{SD}=0.32)$ planning $(\mathrm{M}=1.87, \mathrm{SD}=0.33)$. Here suppression of competing activities and use of emotional social support have the same value $(\mathrm{M}=1.86, \mathrm{SD}=0.34)$. It gives us similar result as Qian et al. (2002) suggests that "cultural value", and 'social attitudes of Nepal " influence the way that families and others perceive ' 'help-seeking behavior'. On the other hand least used two coping strategies included substance uses $(\mathrm{M}=1.29, \mathrm{SD}=0.45)$ and humor $(\mathrm{M}=1.48, \mathrm{SD}=0.50)$.

Mothers $(78 \%)$ were more likely to use coping strategies than the fathers $(2 \%)$. In relation to the education, up to high school level respondent (48\%) and above high school (48\%) used coping strategies. Here this study shows the influence of an occupation on coping strategies that is Home maker: used coping responses were $40 \%$ and labor used coping strategies was only $6 \%$, that is lower than other occupation .

This research depicts the correlation between stress and coping inventory. As the level on stress of the individual increases, parents use more coping strategies also increases $[\mathrm{P}=(0.01)$ as stress level increases and coping also developed during the process of caring disabled children.

\section{CONCLUSION}

This study concluded that the third forth of the parents have high level to clinical significant stress and variables thought to contribute to the stress. There needs to promote positive parenting strategies for dealing with the intellectual disabled children, which helps to reduce problematic parents child relationship. The services of professional counselors and educational package can be developed to parents regarding care of child, its nature and causes for making higher level of understanding to this problem which ultimately helps to decrease the stress level and adopt the coping mechanism.

\section{ACKNOWLEDGEMENT}

I am extremely indebted to my advisor Associate Professor Dr. Bharati Adhikari for constant guidance, support, directions, valuable suggestion and encouragements. I would like to express my sincere thanks to $\mathrm{PhD}$ Center for providing greater forum to publish this article. I am also thankful to all the participants of my study.

\section{BIBLOGRAPHY}


Abidin, R. R. (1995). Parenting Stress Index: Professional Manual (3rd ed.). Odessa, FL:Psychological Assessment Resources

Bailey, D.B. \& Simeonsson, R.J. (1988). Family assessment in early intervention. Columbus, $\mathrm{OH}$ : Merrill Publishing Company.

Bailey, A.B. \& Smith, S.W. (2000). Providing effective coping strategies and supports for families with children with disabilities. Intervention in School and Clinic, 35, (5) 294296.

Beckman, P.A. (1983). Influence of selected child characteristics on stress in families of handicapped infants. American Journal of Mental Deficiency, 88, (2) 150- 156.

Bennett, T., Lingerfelt, B.V., \& Nelson, D.E. (1990). Developing individualized family support plans. Cambridge, MA: Brookline Books.

Burr, W.R., Klein, S.R., Burr, R.G., Doxey, C., Harker, B., Holman, T.B., Martin, P.H., McClure, R.L., Parrish, S.W., Stuart, D.A., Taylor, A.C., \& White, M.S. (1994). Reexamining family stress. Thousand Oaks, CA: Sage Publications, Inc.

Carver, C. S., Scheier, M. F., \& Weintraub, J. K. (1989). Assessing coping strategies: A theoretically based approach. Journal of Personality and Social Psychology, 56, 267283.

Crnic, K.A., Friederich, W.N., \& Greenberg, M.T. (1983). Adaptation of families with mentally retarded children: A model of stress, coping, and family ecology. American Journal of Mental Deficiency, 88, (2) 125-138.

Draper.S, (2009). Coping Mechanism Used By Mothers When Caring for their Adolescent Child With Cerebral palsy. Retrived on May 1, 2013

Eker.L, Tüzün .E.H , (2004), An evaluation of quality of life of mothers of children with cerebral palsy

Glidden,L.M.Floyd,F.J \& Jobe,B.N(2007).Measuring parental daily rewards transition to adulthood. American Journal on Mental Retardation ,112,275-288.

Gupta \& Singhal(2004).Positive perceptions in parents of children with disabilities, Asia Pacific Disability Rehabilitation Journal

Gupta.R.K, Harpreet.k, (2010). Stress among parents of children with intellectual disability. Asia Pacific Disability Rehabilitation Journal, vol.

Gupta, V. B. (2007). Comparison of Parenting Stress in Different Developmental Disabilities .Journal of Developmental and Physical Disabilities, 19, 4, 417-425.

Gupta, A., \& Singhal, N. (2004). Positive perceptions in parents of children with disabilities. Asia Pacific Disability Rehabilitation Journal, 15(1), 22-30

Gupta VB (2007). Comparison of parenting stress in different developmental disabilities. Journal of Developmental \& Physical Disabilities; 19: 417-425.

Karkee R, Yadav BK, Chakravartty A, \& Shrestha DB.( 2008), The prevalence and characteristics of disability in Eastern Nepal, Journal of Kathmandu University Medical,Vol.6,No.1,Issue21,94-97,

Lazarus R. \&, Folkman,S.(1984) Stress, Appraisal, and Coping,234-238. 